JURNAL PENDIDIKAN, p-ISSN 2715-095X, e-ISSN 2686-5041

Volume 30, No.3, Nopember 2021 (445-454)

Online: http://journal.univetbantara.ac.id/index.php/jp

\title{
Peningkatan Pemahaman Konsep Pesawat Sederhana IPA Melalui Metode Demensi Kelas V SDN Gupit 02 Sukoharjo 2015/2016
}

\author{
Sri Wahyuni \\ Guru SDN Gupit 02 Nguter Sukoharjo, Email:yuninguter@gmail.com/085642026666 \\ Received: Oktober 12, $2021 \quad$ Accepted: Oktober 17, $2021 \quad$ Online Published: Nopember 08, 2021
}

\begin{abstract}
Abstrak: Penelitian ini bertujuan untuk meningkatkan aktivitas belajar siswa dalam pembelajaran IPA meningkatkan aktivitas guru dalam pembelajaran IPA Meningkatkan hasil belajar siswa dalam pembelajaran IPA dengan metode demensi demonstrasi eksperimen dan diskusi bagi siswa kelas 5 SD Negeri Gupit02 Nguter. Penelitian ini dilaksanakan pada siswa kelas V SD Negeri Gupit 02 Nguter sebanyak 20 siswa. Hasil penelitian menunjukkan bahwa melalui metode demensi (demonstrasi, eksperimen dan diskusi) dapat meningkatkan hasil belajar siswa dalam pembelajaran IPA di kelas V SD Negeri 02 Gupit, Nguter. Hal tersebut dapat dilihat dengan adanya peningkatan aktivitas siswa dalam pembelajaran dari siklus I mendapat skor rata-rata 27,2 dengan kriteria baik dan siklus II mendapat skor rata-rata 3,15 dengan kriteria baik. Aktivitas guru dalam pembelajaran siklus I menunjukkan skor rata-rata 3,62 dengan kriteria sangat baik dan siklus II dengan skor 3,75 dengan kriteria sangat baik. Hasil belajar siswa dalam pembelajaran IPA mengalami peningkatan dengan rata-rata nilai dari siklus I sebesar 72, 17 dan siklus 2 sebesar 80,00. Sedangkan untuk pencapaian ketuntasan Individual siklus I sebesar 53,33\% dan siklus II sebesar 83,33\%.
\end{abstract}

Kata-kata Kunci: Demensi (demonstrsi, eksperimen dan diskusi), pemahaman, pembelajaran IPA.

\section{Improved Understanding of Science Simple Plane Concepts Through the Dementation Method Class V SDN Gupit 02 Sukoharjo 2015/2016}

\author{
Sri Wahyuni \\ Teacher of SDN Gupit 02 Nguter Sukoharjo,Email:yuninguter@gmail.com
}

\begin{abstract}
This study aims to increase student learning activities in science learning to increase teacher activity in science learning Improve student learning outcomes in science learning with the experimental demonstration and discussion "demensi" on method for 5th grade students of SD Negeri Gupit 02 Nguter. This research was conducted on the fifth grade students of SD Negeri 02 Nguter as many as 20 students. The results showed that the "demensi" on method (demonstration, experimentation and discussion) could improve student learning outcomes in science learning in class V SD Negeri 02 Gupit, Nguter. This can be seen by the increase in student activity in learning from the first cycle to get an average score of 27.2 with good criteria and the second cycle gets an average score of 3.15 with good criteria. The teacher's activity in the first cycle of learning shows an average score of 3.62 with very good criteria and the second cycle with a score of 3.75 with very good criteria. Student learning outcomes in science learning have increased with an average value from the first cycle of 72, 17 and the second cycle of 80.00. Meanwhile, the achievement of individual mastery in the first cycle is $53.33 \%$ and the second cycle is $83.33 \%$.
\end{abstract}


Keywords:ddimensi, understanding, science learning.

\section{Pendahuluan}

Pada Permen 22 tentang Standar Isi SD/MI (2006 : 484) disebutkan bahwa Ilmu Pengetahuan Alam (IPA) berhubungan dengan cara mencari tahu tentang alam secara sistematis, sehingga IPA bukan hanya penguasaan kumpulan pengetahuan yang berupa fakta-fakta, konsep-konsep, atau prinsip-prinsip saja tetapi juga merupakan suatu proses penemuan. Pendidikan IPA diharapkan dapat menjadi wahana bagi siswa untuk mempelajari diri sendiri dan alam sekitar, serta prospek pengembangan kan lebih lanjut dalam menerapkannya di dalam kehidupan sehari-hari. proses pembelajaran yang menekankan pada pemberian pengalaman langsung untuk mengembangkan kompetensi agar menjelajahi dan memahami alam sekitar secara ilmiah. Pengalaman langsung dalam pendidikan IPA dapat diberikan melalui proses demonstrasi atau eksperimen sehingga dapat membantu siswa untuk memperoleh pemahaman yang lebih mendalam tentang alam sekitar. Pembelajaran IPA di SD membuka kesempatan untuk memupuk rasa ingin tahu anak didik secara alamiah. Hal ini akan membantu mereka mengembangkan kemampuan bertanya dan mencari jawaban berdasarkan bukti serta mengembangkan cara berpikir ilmiah. Pembelajaran IPA merupakan wahana untuk mengembangkan anak agar berpikir rasional dan ilmiah, maka pelajaran IPA diupayakan mencapai hasil yang maksimal.Somatowa (2010:2). Pembelajaran IPA di SD Negeri Gupit 02 Kecamatan Nguter khususnya kelas V dijumpai kendala dalam upaya mencapai hasil belajar IPA secara maksimal. Salah satu kendal yang dihadapi adalah kesulitan siswa dalam memahami konsep IPA yang sedang dipelajari, sehingga hasil belajar siswa pada mata pelajaran IPA masih rendah (Suwarto, 2009, 2017). Hasil belajar IPA dari 15 orang siswa kelas V Pada Ulangan Tengah Semester I Dan Ulangan Akhir Semester II tahun pelajaran 2015/2016 sebagian besar masih dibawah KKM yang ditetapkan yaitu 71. Presentase ketuntasan yang dicapai kelas V pada UTS I untuk mata pelajaran IPA adalah $37 \%$ dan presentase ketuntasan UAS I mata pelajaran IPA mencapai 40\%. Adapun nilai rata-rata kelas V untuk Mata pelajaran IPA dari hasil UTS 1 adalah 67 dan hasil UAS I mencapai 69. Rata-rata nilai ulangan harian ke-1 semester 2 tahun pelajaran 2015/2016 hanya mencapai 64,33 dengan presentase ketuntasan sebesar 36,67\%. Dari data nilai tersebut menunjukkan bahwa hasil belajar siswa wa masih rendah. rendahnya hasil belajar siswa wa pada mata pelajaran IPA disebabkan oleh pemahaman siswa terhadap konsep IPA masih rendah

Berdasarkan uraian di atas agar dapat disimpulkan bahwa guru harus mampu menyelenggarakan pembelajaran IPA dengan menggunakan keragaman metode yang melibatkan aktivitas siswa siswa sehingga siswa mendapatkan pengalaman langsung. Pengalaman langsung dalam pembelajaran IPA diberikan agar siswa dapat mampu mengeksplorasi pengetahuan yang dimiliki, mampu berpikir rasional dan ilmiah dalam upaya memahami konsep IPA yang dipelajari. Pembelajaran IPA juga harus mampu memberi kesempatan kepada siswa untuk mengembangkan rasa ingin tahu terhadap konsep yang sedang dipelajari sehingga mencapai hasil belajar yang maksimal.

Pihak sekolah dan orang tua/ wali siswa kelas V SD Negeri Gupit 02 Kecamatan Nguter berharap agar nilai hasil belajar siswa pada mata pelajaran Ilmu Pengetahuan Alam dapat meningkat, minimal dapat mencapai KKM yang telah ditentukan pihak sekolah. Bahkan kalau bisa dapat memperoleh nilai yang memuaskan. Harapan lain yang ingin diwujudkan dalam pembelajaran Ilmu Pengetahuan Alam di kelas V Adalah agar siswa 
menguasai materi pelajaran ilmu pengetahuan alam sebagai bekal untuk menghadapi Ulangan Kenaikan Kelas.

Mencermati uraian di atas, maka jelas terlihat adanya kesenjangan antara kenyataan dengan harapan. Kenyataan yang ada menunjukkan masih rendahnya pemahaman siswa terhadap konsep IPA yang berdampak pada rendahnya hasil belajar siswa kelas V SD Negeri Gupit 02 Kecamatan Nguter, khususnya untuk mata pelajaran Ilmu Pengetahuan Alam. Guru dan orangtua wali murid mempunyai harapan agar semua siswa dapat memperoleh nilai yang mencapai KKM untuk mata pelajaran Ilmu Pengetahuan Alam. Bahkan kalau bisa memperoleh nilai yang memuaskan sehingga mencapai nilai KKM, siswa siap mengikuti pembelajaran ilmu pengetahuan untuk KD berikutnya.

Kondisi di lapangan menunjukkan kesenjangan antara kondisi riil dan harapan, maka perlu dicarikan solusi / pemecahan masalah yang dihadapi agar Siswa lebih mudah memahami konsep dalam pembelajaran IPA sehingga hasil belajar siswa juga mengalami peningkatan. Adapun solusi untuk mengatasi masalah yang berkaitan dengan rendahnya tingkat pemahaman siswa terhadap konsep dalam pembelajaran IPA adalah dengan melaksanakan Penelitian Tindakan Kelas (PTK). Penelitian tindakan kelas PTK dilakukan untuk memperbaiki proses pembelajaran dengan harapan terjadi peningkatan pemahaman dan hasil belajar siswa dalam pembelajaran IPA.

Rendahnya hasil belajar yang diperoleh siswa diindikasikan disebabkan karena kurangnya minat siswa. Salah satu metode pembelajaran yang dianggap dapat meningkatkan pemahamanpembelajaran adalah metodeDemensi(Demostrasi Eksperimen Diskusi). Metode "demensi" merupakan metode pembelajaran hasil perpaduan antara metode demonstrasi, eksperimen dan diskusi yang dikemas melalui akronim (singkatan kata) menjadi metode "demensi". Menurut La Iru (2012: 30),menerangkan bahwa metode demonstrasi merupakan metode mengajar yang menyajikan bahan pelajaran dengan mempertunjukkan secara langsung objek atau cara melakukan sesuatu sehingga dapat mempelajarinya secara proses. Penggunaan metode demonstrasi dapat diterapkan dengan syarat memiliki keahlian untuk mendemonstrasikan penggunaan alat atau melaksanakan kegiatan tertentu seperti kegiatan sesungguhnya. Keahlian mendemonstrasikan tersebut harus dimiliki oleh guru dan pelatih yang ditunjuk (Aqib, 2016:104). Menurut Ramayulis (2005: 245), metode demonstrasi dalam proses pengajaran merupakan "metode atau cara mengajar yang menggunakan suatu kerja fisik atau pengoperasian peralatan atau benda untuk menjelaskan sesuatu materi ajar”.Drs. Imansyah Alipandie (1984: 56) menjelaskan metode demonstrasi adalah suatu metode mengajar yang dilakukan oleh guru atau seseorang lainnya dengan memperlihatkan kepada seluruh kelas tentang suatu proses atau suatu cara melakukan sesuatu.

Kelebihan metode demonstrasi menurut Syaiful Bahri Djamarah (2008:211) antara lainperhatian siswa dapat dipusatkan pada hal-hal yang dianggap penting oleh guru sehingg hal yang penting itu dapat diamati secara teliti, selain itu, perhatian siswa pun lebih mudah dipusatkan kepada proses belajar mengajar dan tidak kepada yang lainya,dapat membimbing siswa ke arah berpikir yang sama dalam satu saluran pikiran yang sama.Ekonomis dalam jam pelajaran di sekolah dan ekonomis dalam waktu yang panjang dapat diperlihatkan melalui demonstrasi dengan waktu yang pendek,dapat mengurangi kesalahan-kesalahan bila dibandingkan dengan hanya membaca atau mendengarkan, karena murid mendapatkan gambaan yang jelas dari hasil pengamatannya,karena gerakan dan proses dipertunjukan maka tidak memerlukan keterangan-keterangan yang banyak.Beberapa persoalan yang menimbulkan petanyaan atau keraguan dapat diperjelas 
waktu proses demonstrasi.Kekurangan metode demonstrasi yaitu derajat visibilitasnya kurang, peserta didik tidak dapat melihat atau mengamati keseluruhan benda atau peristiwa yang didemonstrasikan kadang-kadang terjadiperubahan yang tidak terkontrol.Metode demonstrasi menggunakan alat-alat yang khusus, kadang-kadang alat itu susah didapat. Pelaksanakan metode demonstrasi yang baik atau efektif, ada beberapa langkah yang harus dipahami dan digunakan oleh guru, yang terdiri dari perencanaan, uji coba dan pelaksanaan oleh guru lalu diikuti oleh murid dan diakhiri dengan adanya evaluasi (J.J Hasibuan dan Mujiono,2008:31). Demonstrasi merupakan metode yang tidak wajar bila alat yang didemonstrasikan tidak dapat diamati secara seksama, dalam mengadakan pengamatan terhadap hal-hal yang didemonstrasikan diperlukan pemusatan perhatian. Hal ini banyak diabaikan oleh peserta didik.Tidak semua hal dapat didemonstrasikan di kelas.Memerlukan banyak waktu sedangkan hasilnya kadang-kadang sangat minimum.Kadang-kadang hal yang didemonstrasikan di kelas akan berbeda jika proses itu didemonstrasikan dalam situasi nyata atau sebenarnya.Agar demonstrasi mendapatkan hasil yang baik diperlukan ketelitian dan kesabaranMetode eksperimen merupakan metode yang dalam penyajian materinya melalui percobaan atau mencobakan sesuatu serta mengamati secara proses. eksperimen sulit dipisahkan dengan demonstrasi karena keduanya kemungkinan dapat digunakan secara bersama. eksperimen digunakan bahwa guru dan siswa mencoba mengerjakan sesuatu secara mengamati proses dan hasil pekerjaannya (La Iru, 2012: 32)Metode mengajar diskusi merupakan metode mengajar yang dalam pembahasan dan penyajian materi nya melalui suatu problem atau pernyataan yang harus diselesaikan berdasarkan pendapat atau keputusan bersama (La Iru, 2012:25). Menurut Trianto (2007: 117) diskusi merupakan komunikasi seseorang berbicara satu dengan yang lain saling berbagi Gagasan dan pendapat. Sedangkan menurut Arends ( dalam Trianto, 2007: 117), diskusi merupakan dalam pembelajaran mempunyai arti suatu situasi di mana guru dengan siswa atau siswa dengan siswa wa yang lain saling bertukar pendapat secara lisan, saling berbagi gagasan dan pendapat.

Menurut Amri (2010:165), diskusi adalah sebuah interaksi antara dua orang atau lebih (sebagai suatu kelompok). Biasanya komunikasi antara mereka atau kelompok berupa salah satu ilmu Atau pengetahuan dasar yang akhirnya memberikan rasa pemahaman yang baik dan benar. Diskusi bisa berupa apa saja yang awalnya sebuah topik. dari topik inilah diskusi berkembang, dibincangkan dan pada akhirnya menghasilkan suatu pemahaman dari topik tersebut. Aqib (2016:106) juga memberikan pengertian bahwa diskusi merupakan interaktif antara siswa dengan siswa atau siswa dengan guru untuk menganalisis, memecahkan masalah, menggali memperdebatkan topik atau permasalahan tertentu. Berdasarkan pengertian demonstrasi eksperimen dan diskusi dapat disimpulkan bahwa metode "demensi" yang merupakan perpaduan dari ketiga metode tersebut merupakan metode yang digunakan untuk menyajikan materi melalui proses: 1) melakukan, 2) mengamati proses, 3) mencoba, dan 4) Melakukan diskusi untuk membahas permasalahan yang diperoleh dari hasil pengamatan dan percobaan agar memperoleh kesimpulan berdasarkan pembahasan bersama.Indikator untuk mengukur keberhasilan tindakan peningkatan hasil belajar IPA antara lain aktivitas siswa dalam pembelajaran IPA menggunakan metode demonstrasi, eksperimen dan diskusi meningkat dengan kriteria sekurang-kurangnya baik. Aktivitas guru dalam pembelajaran IPA menggunakan metode demonstrasi, eksperimen dan diskusi meningkat dengan kriteria sekurang-kurangnya baik, 80\% siswa kelas V SD Negeri Gupit 02 Kecamatan Nguter mengalami ketuntasan belajar Individual sebesar $\geq 71$ dalam pembelajaran IPA. Sunaryo (2011) dalam 
peneltiannyan menyatakan bahwa belajar membutuhkan motivasi yang tinggi dalam jangka wkatu lama oleh karena itu seorang pendidik hendaknya membangkitakn motivasi belajar siswa dengan berbagai cara. Salah satu cara membangkitkan motivasi belajar adalah dengan memberikan penghargaan dengan membangkitkan motivasi hasil belajar akan semakin meningkat

Dari latar belakang masalah di atas dapat dirumuskan permasalahan ini sebagai berikut "Apakah melalui pembelajaran dengan metode "demensi" (demonstrasi, eksperimen dan diskusi)dapat meningkatkan pemahaman siswa terhadap konsep pesawat sederhana dalam mata pelajaran IPA di kelas V SD Negeri Gupit 02 Kecamatan Nguter semester 2 tahun ajaran 2015/2016". Tujuan dari diadakannya penelitian ini agar dapat menjawab permasalahan yang telah dirumuskan yaitu supaya aktivitas belajar siswa, aktivitas guru serta peningkatan hasil belajar dapat dicapai oleh siswa kelas V SD Negeri Gupit 02 Kecamatan Nguter dengan menggunakan model pembelajaran demensi demonstrasi eksperimen dan diskusi.

\section{Metode Penelitian}

Penelitian tindakan kelas ini dilaksanakan pada semester II tahun pelajaran 2015/2016. Penelitian ini dilaksanakan kurang lebih selama 3 bulan. Penelitian ini dilaksanakan di kelas V SD Negeri Gupit 02 Kecamatan Nguter. Alasan peneliti memilih tempat tersebut karena pada tahun pelajaran 2015/2016 semester II peneliti mengajar di kelas V SD Negeri Gupit 02. Subjek dalam penelitian ini adalah siswa kelas V SD Negeri Gupit 02 Kecamatan Nguter dengan jumlah siswa 20. Penelitian tindakan kelas ini menggunakan dua sumber data yaitu sumber data primer dan data sekunder. Sumber data primer penelitian tindakan kelas ini adalah siswa kelas V Sekolah Dasar Negeri Gupit 02 Kecamatan Nguter pada semester II tahun pelajaran 2015/2016. Adapun sumber data sekunder di ambil dari hasil pengamatan mengenai aktivitas siswa dan aktivitas guru yang dilakukan oleh kolaborator selama proses penelitian.

Model Penelitian Tindakan terdiri dari 4 tahap (Suharsimi, 2009:16)yaitu perencanaan, pelaksanaan tindakan, pengamatan dan refleksi, dalam penelitian tindakan kelas terdapat dua teknik pengumpulan data yaitu teknik tes dan teknik non tes. pengumpulan data dengan teknis tes terdapat tiga bentuk tes yaitu tes tertulis tes lisan dan tes perbuatan. sedangkan pengumpulan dengan menggunakan teknik non tes dapat dilakukan dengan beberapa cara diantaranya melalui wawancara, observasi, kuesioner dan lain-lain. Dalam penelitian ini teknik pengumpulan data yang digunakan adalah observasi teknik tes dokumentasi dan catatan lapangan. Metode observasi dalam penelitian ini berisi catatan yang menggambarkan bagaimana aktivitas siswa dalam pembelajaran IPA dengan menggunakan metode demonstrasi, eksperimen dan diskusi. Metode tes dalam penelitian ini digunakan untuk mengukur kemampuan dasar dan pencapaian atau prestasi belajar. metode dokumentasi dilakukan untuk memperkuat data yang diperoleh dalam observasi, sedangkan catatan lapangan berisi catatan guru selama pembelajaran berlangsung apabila ada hal yang muncul dalam proses pembelajaran.

Analisis data dalam penelitian ini menggunakan teknik analisis deskriptif kualitatif kuantitatif. Analisis data secara kualitatif digunakan untuk menganalisis data kualitatif, seperti hasil observasi dan studi dokumentasi. Penelitian tindakan kelas ini dilaksanakan dalam dua siklus tindakan dan dilaksanakan sesuai dengan hasil yang ingin 
dicapai. Siklus pertama dilaksanakan selama dua minggu dan siklus kedua juga dilaksanakan dalam waktu dua minggu. Siklus dalam penelitian tindakan kelas ini dilakukan empat tahapan yang dilaksanakan secara berurutan yaitu perencanaan, pelaksanaan tindakan, observasi dan refleksi dilanjutkan dengan perbaikan atau peningkatan yang diharapkan dapat tercapai. Tahap perencanaan peneliti membuat perencanaan untuk menentukan langkah-langkah pelaksanaan tindakan, tahap observasi dilakukan dengan mengamati proses pembelajaran sebagai upayauntuk merekam proses yang terjadi selama pembelajaran berlangsung. Tahap refleksi dilaksanakan sebagai upaya untuk mengkaji apa yang sudah dilaksanakan, yang sudah dihasilkan kan kan, mengapa hal tersebut bisa terjadi dan apa yang perlu dilakukan selanjutnya.

\section{Hasil penelitian}

Penelitian yang telah dilakukan, oleh Ilham Farhanudin ( 2013) menyatakan hasil analisis data dan diskusi yang dilakukan dapat disimpulkan bahwa ada pengaruh yang signifikan antara penerapan metode simulasi dengan hasil belajar siswa pada mata pelajaran IPA. Peningkatan berupa aktivitas belajar siswa, aktivitas guru dan peningkatan hasil belajar siswa. Hal ini membuktikan bahwa metode "demensi" sangat cocok diterapkan dalam pembelajaran terutama dalam mata pelajaran IPA karena metode "demensi" dapat memaksimalkan proses pembelajaran.

Nilai rata-rata 1 kali ulangan IPA semester 2 kelas V SD Negeri Gupit 02 adalah 64,33 dengan 6 siswa mendapatkan nilai tuntas dengan persentase ketuntasan klasikalnya adalah 36,67 \%. nilai tertinggi yang diperoleh adalah 85 dan nilai terendah 35 . Dari kondisi tersebut guru melakukan perbaikan tindakan pembelajaran dengan menggunakan metode "demensi" yaitu kolaborasi antara demonstrasi, eksperimen dan diskusi untuk meningkatkan aktivitas siswa, aktivitas guru dan hasil belajar dalam pembelajaran IPA. tindakan yang dilakukan guru dalam siklus I yang dilaksanakan dalam tiga pertemuan diawali dengan pretest diperoleh nilai rata-rata kelas sebesar 64,33 dengan jumlah siswa yang mendapat nilai tuntas sebanyak 6 orang dengan persentase ketuntasan klasikal sebesar $36,67 \%$ perolehan nilai pretest belum memenuhi indikator keberhasilan. Dari hasil pretest tersebut maka guru melakukan tindakan pembelajaran menggunakan metode "demensi".

\begin{tabular}{clll}
\multicolumn{3}{c}{ Tabel 1. Daftar Distribusi Frekuensi Hasil Belajar IPA Siklus I } \\
\hline $\begin{array}{c}\text { Interval } \\
\text { Nilai }\end{array}$ & Frekuensi & Frekuensi Relatif & Kualifikasi \\
\hline 100 & & & Tuntas \\
$95-99$ & - & $3,33 \%$ & Tuntas \\
$90-94$ & 1 & $3,33 \%$ & Tuntas \\
$85-89$ & 1 & $13,33 \%$ & Tuntas \\
$80-84$ & 2 & $30 \%$ & Tuntas \\
$75-79$ & 4 & $20 \%$ & Tuntas \\
$70-74$ & 3 & $30 \%$ & Tuntas \\
$65-69$ & 4 & $13,33 \%$ & Belum tuntas \\
$60-64$ & 2 & $13,33 \%$ & Belum tuntas \\
$55-59$ & 2 & $3,33 \%$ & Belum tuntas \\
$50-54$ & 1 & $100 \%$ & Belum tuntas \\
Jumlah & 20 & & \\
\hline
\end{tabular}


Pada data menunjukkan perolehan hasil belajar IPA melalui metode "demensi" (demonstrasi, eksperimen dan diskusi) bahwa pada siklus I siswa mengalami ketuntasan belajar sebanyak $53,33 \%$ sedangkan $46,67 \%$ siswa belum tuntas dalam belajar, hal ini ditunjukkan bahwa 9 siswa mengalami ketuntasan belajar dan 6 siswa belum tuntas. Nilai terendah yang dicapai oleh siswa 50 dan nilai tertinggi 90 dengan rerata 72,17.

Hasil belajar siswa kelas V SD Negeri Gupit 02 Kecamatan Nguter pada mata pelajaran IPA materi pesawat sederhana berdasarkan hasi data penelitian mengalami peningkatan dibandingkan nilai pada kondisi awal. Pencapaian pencapaian hasil belajar siswa kelas V dalam pembelajaran IPA Pada siklus I yang dilaksanakan menggunakan metode "demensi" belum mencapai target yang ditetapkan. Siswa yang mencapai ketuntasan belajar baru 53,33\%, sedangkan target ketuntasan belajar yang ditetapkan dalam indikator kinerja sekurang-kurangnya $80 \%$ siswa mengalami ketuntasan belajar individual. Refleksi dilaksanakan untuk menganalisa pembelajaran yang telah berlangsung pada siklus I, berdasarkan data-data yang telah dikumpulkan. Data-data tersebut meliputi data observasi saat pembelajaran dan hasil evaluasi posttest. Refleksi di laksanakan bersama kolaborator Untuk bahan pertimbangan dalam memperbaiki pembelajaran siklus berikutnya. Data mengenai hasil belajar siswa kelas V SD Negeri Gupit 02 dalam pembelajaran IPA dengan menggunakan metode "demensi" (demonstrasi, eksperimen dan diskusi)pada siklus II dapat dilihat pada tabel berikut:

Tabel 2. Daftar Distribusi Frekuensi Hasil Belajar IPA Siklus II

\begin{tabular}{llll}
\hline Interval Nilai & Frekuensi & Frekuensi Relatif & Kualifikasi \\
\hline 100 & 1 & $6,67 \%$ & $\begin{array}{l}\text { Tuntas } \\
\text { Tuntas }\end{array}$ \\
$95-99$ & & & Tuntas \\
$90-94$ & 3 & $16,67 \%$ & Tuntas \\
$85-89$ & 4 & $20 \%$ & Tuntas \\
$80-84$ & 4 & $20 \%$ & Tuntas \\
$75-79$ & 4 & $20 \%$ & Tuntas \\
$70-74$ & - & - & Belum tuntas \\
$65-69$ & 1 & $6,67 \%$ & Belum tuntas \\
$60-64$ & 3 & $10 \%$ & Belum tuntas \\
$55-59$ & - & - & Belum tuntas \\
$50-54$ & - & - & \\
Jumlah & 20 & $100 \%$ & \\
\hline
\end{tabular}

data pada tabel diatas menunjukkan perolehan hasil belajar IPA melalui metode "demensi" (demonstrasi, eksperimen dan diskusi). Berdasarkan data tersebut siswa yang mencapai ketuntasan belajar sebesar $83,88 \%$, sedangkan $16,67 \%$ siswa belum tuntas dalam belajar. Hal ini menunjukkan bahwa 13 siswa mencapai ketuntasan belajar dan 2 siswa belum tuntas. Nilai terendah yang diperoleh adalah 60 , sedangkan nilai tertinggi 100 dengan rerata 80,00. Dari data tersebut, dapat dibaca bahwa pencapaian hasil belajar IPA yang dilaksanakan menggunakan metode "demensi"(demonstrasi, eksperimen dan diskusi) telah mencapai target yang ditetapkan dalam indikator kinerja yaitu sekurang-kurangnya $80 \%$ siswa mengalami ketuntasan belajar Individual $\geq 71$.

\section{Pembahasan}

Penelitian yang dilakukan oleh Fartati. 2013.Penerapan Metode Demonstrasi untuk Meningkatkan Hasil Belajar Siswa Pada Materi Penyebab Benda Bergerak di Kelas II SD 
No. 1 Polanto Jaya menunjukkan bahwa metode demonstrasi dapat meningkatkan hasil belajar siswa kelas 2 SD No. 1 Polanto Jaya pada materi benda bergerak. Senada dengan Fartati (2013), Asep Somantri, (2014) dalam penelitiannya juga menyatakan penerapan metode eksperimen dalam pembelajaran IPA dapat meningkatkan hasil belajar IPA siswa kelas V sekolah dasar. Senada dengan penelitian tersebut Yety Purnawirawanti. (2013) juga melakukan penelitian yang sama dengan hasil melalui metode demonstrasi dan simulasi berpengaruh terhadap prestasi belajar, metode simulasi berpengaruh lebih efektif daripada metode demonstrasi.

Kesimpulan dari penelitian tindakan kelas ini adalah penggunaan metode Demensi (Demonstrasi, Eksperimen, Diskusi) dapat meningkatkan pemahaman siswa terhadap konsep pesawat sederhana.Berdasarkan hasil penelitian, terdapat peningkatan aktivitas belajar siswa dari siklus I siklus II. Pada siklus I siswa belum terbiasa dengan pembelajaran menggunakan metode "demensi"(demonstrasi, eksperimen dan diskusi). Siswa masih tampak bingung ketika melaksanakan aktivitas diskusi dan percobaan mengenai pesawat sederhana. Aktivitas siswa pada pembelajaran siklus IIsudah mengalami peningkatan, hal ini ini dapat dilihat dari perolehan skor yang mengalami peningkatan pada siklus II. Antusias siswa untuk melaksanakan kegiatan pembelajaran semakin meningkat. Siswa terlihat semakin aktif dalam kegiatan tanya jawab, ada kegiatan diskusi keberanian siswa untuk mengutarakan pendapat juga mengalami peningkatan. Siswa sudah lebih terampil dalam melaksanakan eksperimen.

Skor yang diperoleh oleh guru dalam pembelajaran pada siklus I adalah 14 dengan kriteria baik, sedangkanpada siklus II memperoleh skor 15 dengan kriteria sangat baik. Berdasarkan data tersebut dapat dikatakan bahwa aktivitas guru dalam pembelajaran dengan menggunakan metode "demensi" (demonstrasi, eksperimen dan diskusi) mengalami peningkatan pada siklus II. Pada siklus I, aktivitas guru dalam pembelajaran sudah baik, namun masih ada yang perlu ditingkatkan yaitu pada aktivitas membimbing siswa dalam menyimpulkan dan menyusun laporan hasil percobaan. Aktivitas guru dalam pembelajaran pada siklus II mengalami peningkatan. Pada kegiatan membimbing siswa dilakukan guru dengan baik sehingga siswa lebih aktif dalam pembelajaran.

Hasil belajar IPA dengan materi pesawat sederhana dari pra siklus ke siklus I dan siklus II mengalami peningkatan. Hasil belajar pra siklus rata-rata 64,33 dengan ketuntasan belajar individu yang diperoleh adalah 36,67\% dengan jumlah siswa tuntas sebanyak 6 siswa. Untuk siklus I rata-rata hasil belajar adalah 72,17 dengan ketuntasan belajar individual 53,33\% dengan jumlah siswa tuntas 8 siswa. Sedangkan untuk siklus II hasil belajar adalah 80,00 dengan ketuntasan belajar individual yang diperoleh siswa 83,33\% dengan jumlah siswa tuntas 13 siswa. Berdasarkan data tersebut dapat dijelaskan bahwa telah terjadi peningkatan hasil belajar dari siklus I siklus II. Hasil belajar IPA yang diperoleh sudah mencapai target KKM kelas yang ditetapkan yaitu sekurang-kurangnya $80 \%$ siswa mengalami ketuntasan belajar Individual sebesar $\geq 71$. Hal ini membuktikan bahwa metode "demensi" dapat meningkatkan hasil belajar siswa, dibuktikan dengan ketuntasan belajar yang dicapai pada siklus II. Peningkatan hasil belajar yang dicapai siswa dari siklus I sampai siklus II membuktikan bahwa pembelajaran dengan metode "demensi" dapat meningkatkan pemahaman siswa terhadap konsep pesawat sederhana.

Penelitian yang telah dilakukan menunjukkan telah terjadi peningkatan berupa aktivitas belajar siswa aktivitas guru dan peningkatan hasil belajar siswa. Hal ini membuktikan bahwa metode "demensi" sangat cocok diterapkan dalam pembelajaran terutama dalam mata pelajaran IPA karena dapat memaksimalkan proses 
pembelajaran. aktivitas belajar siswa masih kurang ketika belum menggunakan metode "demensi"(demonstrasi, eksperimen dan diskusi). Setelah pembelajaran dilaksanakan dengan menggunakan metode tersebut terjadi peningkatan aktivitas belajar siswa. Siswa lebih percaya diri dalam berkomunikasi sehingga aktivitas tanya jawab dan kerjasama menjadi lebih baik, karena kerjasama sangat diperlukan untuk memecahkan suatu permasalahan yang dihadapi.Menurut Muhibbin Syah (2000: 22) Metode demonstrasi adalah metode mengajar dengan cara memperagakan barang, kejadian, aturan, dan urutan melakukan suatu kegiatan, baik secara langsung maupun melalui penggunaan media pengajaran yang relevan dengan pokok bahasan atau materi yang sedang disajikan

Melalui metode demensi demonstrasi eksperimen dan diskusi kemampuan dan kreativitas guru dalam pembelajaran mengalami peningkatan, diantaranya adalah kemampuan guru dalam menciptakan suasana kelas yang lebih menyenangkan, sehingga siswa tidak akan merasa bosan selama pembelajaran berlangsung. Peningkatan aktivitas dan kreativitas guru dapat memacu siswa agar lebih kreatif dalam proses pembelajaran sehingga suasana kelas akan lebih hidup dan dapat mencapai tujuan pembelajaran yang telah ditetapkan secara maksimalhasil belajar siswa juga meningkat Setelah pembelajaran dilaksanakan dengan menggunakan metode "demensi"(demonstrasi, eksperimen dan diskusi).Hal ini dikarenakan semangat siswa mulai terpacu untuk lebih aktif dalam belajar.

\section{Simpulan dan Saran}

Berdasarkan hasil penelitian mengenai peningkatan pemahaman siswa terhadap konsep pesawat sederhana dalam mata pelajaran IPA melalui metode "demensi"(demonstrasi, eksperimen dan diskusi) di kelas V SD Negeri Gupit 02 Kecamatan Nguter, peneliti dapat menyimpulkan bahwa metode "demensi" (demonstrasi, eksperimen dan diskusi) dapat meningkatkan aktivitas dan minat belajar siswa dalam pembelajaran IPA, metode tersebut juga dapat meningkatkan aktivitas guru dalam pembelajaran IPA. Hal ini dapat dilihat dari hasil penelitian yang menunjukkan adanya peningkatan aktivitas siswa dan guru dari siklus I hingga siklus II. Peningkatan aktivitas siswa dan guru dalam pembelajaran IPA melalui metode "demensi"(demonstrasi, eksperimen dan diskusi) menyebabkan peningkatan pemahaman siswa terhadap konsep pesawat sederhana, sehingga prestasi belajar siswa dalam pembelajaran IPA juga mengalami peningkatan sesuai dengan harapan Guru dan Orang Tua. Implikasi dalam hasil penelitian ini adalah guru yang sedang mengajar cari temukan dan terapkan teknik atau cara serta media yang dapat membantu siswa lebih mudah memahami materi pelajaran dan tumbukan semangat belajar yang tinggi pada siswa sehingga materi yang disampaikan guru dapat dimengerti dan dipahami dengan baik.

Saran yang dapat peneliti sampaikan setelah melaksanakan perbaikan pembelajaran antara lain penggunaan metode "demensi" (demonstrasi, eksperimen dan diskusi) dapat meningkatkan aktivitas siswa dan guru dalam pembelajaran IPA, maka disarankan bagi guru untuk menggunakan metode tersebut agar aktivitas belajar siswa dapat meningkat. Dengan menggunakan metode "demensi" (demonstrasi, eksperimen dan diskusi) hasil belajar siswa dalam pembelajaran IPA dapat meningkat, Tidak ada salahnya untuk meningkatkan hasil belajar pada mata pelajaran lain disarankan untuk menggunakan pendekatan pembelajaran yang inovatif, salah satunya adalah model pembelajaran kontekstual yang menerapkan metode "demensi" (demonstrasi, eksperimen dan diskusi). Kepala sekolah memberikan motivasi dan fasilitas kepada para guru yang ada di sekolahnya untuk berkompetisi dalam meningkatkan kemampuan dirinya dalam 
melaksanakan pembelajaran yang inovatif, sehingga berakibat pada meningkatnya prestasi para siswa dan prestasi sekolah

\section{Daftar Rujukan}

Alipandie, Imansyah. (1984). Didaktik Metodik Pendidikan. Surabaya: Usaha. Nasional.

Amri, S. dan Ahmadi K. I. (2010). Proses Pembelajaran Kreatif dan Inovatif. Dalam Kelas. Jakarta : Prestasi Pustaka Raya

Aqib, Zainal. (2016). Penelitian Tindakan Kelas Beserta Sistematika Proposal dan.

Laporannya. Jakarta: Bumi Aksara.

Fartati. 2(013).Penerapan Metode Demonstrasi Untuk Meningkatkan Hasil Belajar Siswa Pada Materi Penyebab Benda Bergerak Di Kelas II SD No. 1 Polanto Jaya. Jurnal Kreatif Tadulako Online Volume 3(4).

Hasibuan, N. (2013). Kriteria Pemilihan Metode Mengajar dalam Kegiatan Pembelajaran. http://ejournal.iaintulungagung.ac.id/index.php/taalum/article/view/541 : ta'allum volume 01.

Irham Falahudin. 2013. Penerapan Metode Simulasi Tentang Perkembangbiakan Vegetatif Buatan dalam Meningkatkan Hasil Belajar Siswa Pada Mata Pelajaran IPA di Madrasah Ibtidaiyah Pangeran Aji Kabupaten Oku Timur.

http://jurnal.radenfatah.ac.id/index.php/tadib

J.J.Hasibuan dan Moedjiono. (2008). Proses Belajar Mengajar. Bandung : PT. Remaja Rosdakara

La Iru dan La Ode Safiun Arihi. (2012). Analisis Penerapan: Pendekatan, Metode,. Strategi, dan Model-Model Pembelajaran. Yogyakarta: Multi Presindo

Muhibbin, Syah. (2000). Psikologi Pendidikan Dengan Pendekatan Baru. Bandung: Remaja Rosdakarya

Ramayulis. (2005). Metodologi Pendidikan Agama Islam. Jakarta: Kalam Mulia

Samatowa, Usman. (2010). Pembelajaran IPA di Sekolah Dasar. Jakarta: PT Indeks

Somantri, (2014). Penerapan Metode Eksperimen Untuk Meningkatkan Hasil Belajar IPA Siswa Kelas V SD. Jurnal Pendidikan Guru Sekolah Dasar.

Suharsimi. Arikunto, (2009). Prosedur Penelitian suatu Pendekatan Praktis. Jakarta: Rineka Cipta

Sunaryo (2011). Pengaruh Metode Simulasi dan Motivasi Belajar Siswa terhadap Prestasi Belajar Ilmu Pengetahuan Sosial kelas IV SD Negeri 2 Lugosobo Gebang Purworejo tahun pelajaran 2011/2012. Jurnal Profesi Pendidik Volume 2 (1)

Suwarto, S. (2009). Pengembangan tes dan analisis hasil tes yang terintegrasi dalam program komputer. Jurnal Penelitian dan Evaluasi Pendidikan, 13(1), 40-56.

Suwarto, S. (2017). Pengembangan tes ilmu pengetahuan alam terkomputerisasi. Jurnal Penelitian dan Evaluasi Pendidikan, 21(2), 153-161.

Syaiful Bahri Djamarah, Aswan zain. (2006). Strategi Belajar Mengajar. Jakarta: Rineka Cipta.

Trianto, (2007). Model-model Pembelajaran iInovatif berorientasi kontruktivistik. Jakarta: Prestasi Pustaka.

Yety Purnawirawanti. (2013). Pendekatan Kontekstual Melalui Metode Demonstrasi dan Simulasi dalam Pembelajaran IPA ditinjau dari Kecerdasan Spasial dan Interaksi Sosial Siswa. Jurnal Inkuiri, Volume 2(1) 